\title{
DISSERTAÇÕES E TESES DEFENDIDAS
}

Planejamento Famillar: REALIDADE SOCIAL E IGREJA Dissertação de Mestrado em Teologia Moral - 114 páginas.

\section{Pe. Silvio Natalino de Souza}

HAULDADE DE TWOLOGH

NOSSA SENHOW

DA ASSUNCEO

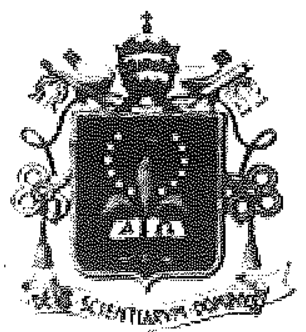

O autor enfrenta o difícil tema do Planejamento Familiar, mostrando especialmente o confronto da realidade social brasileira com a defesa da vida, como missão prioritária da Igreja. Ressalta a problemática dos contraceptivos, sua história, vantagens e desvantagens bem como a atitude cristã diante dos métodos. $\mathrm{O}$ autor demonstra em sua pesquisa que, para a Igreja, a Paternidade e a Maternidade Responsáveis são um direito e um dever dos casais cristãos hoje.

ANDANDO POR El MUNDo EN bUSCA DE JUSTIÇA PARA LOS POBRES DE

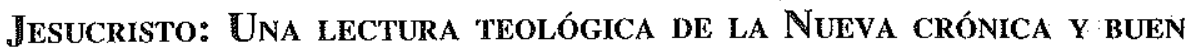
gobierno de Telipe Guaman Poma de Ayala (1535-1615)

Dissertação de Mestrado em Missiologia - 211 páginas.

Fernando Amaya Farias

FOS.GEMULACHO

ESTDOS

(A)

Teologia Dogerdutical

- MESTMDO

A reflexão teológica feita a partir de uma das crônicas do século XVI, como é o caso da obra do indígena andino Felipe Guaman Poma de Ayala, levou o autor a assumir como pressuposto hermenêtico a defesa da alteridade cultural e a denúncia da assimetria social que se impos sobre os povos da América ao longo destes 500 anos de colonização. É dessa forma que o autor realiza o seu trabalho de pesquisa tratando do contexto histórico cultural, da relevância salvífica das religiões indígenas, da defesa da justiça, do protagonismo indígena e missão da Igreja.

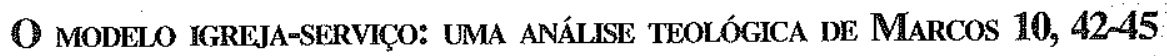
Dissertação de Mestrado em Estudos Bíblicos - 157 páginas

Bruno Godofredo Glaab

Marcos 10,42-45 faz parte da perícope de Mc 10,32-45. Foi colocadó no contexto da subida para Jerusalém como esclarecimento à cegueira dos discípulos. O serviço é visto à partir da cruz. Os cristãos das comunidades de Marcos enfrentaram sérios conflitos como o domí- 
nio romano, a religião da Torá e a Guerra Judaica. É nesse contexto que o autor trata do serviço: servir como Jesus serviu não é um simples gesto, mas uma atitude de vida que deslegitima a ordem política e social vigente.

Carnaval e Religião no morro da MANGUEIRA: REAlidade SócioRELIGIOSA E DESAFIOS PASTORAIS

Dissertação de Mestrado em Missiologia - 320 páginas.

\section{Pe. Orazio Anselmi}

O autor da presente dissertação realizou uma exaustiva pesquisa, à qual somou sua experiência pessoal de vivência pastoral-evangelizadora no Morro da Mangueira. É um trabalho inédito que desvenda as raízes, a herança histórica e os personagens principais da vida comunitária da Mangueira. O Carnaval, como mito e festa, é estudado ao lado da Religião e Cultura Popular. Devoção popular, ritos de iniciação, devoção mariana, procissões, sincretismo, o lúdico e o religioso, são temas que emergem com muito vigor na presente tese. $O$ autor propõe três pistas para o trabalho missionário-pastoral no Morro da Mangueira: Relação (Viver como Conviver), Transformação (Viver como Libertados), Animação (Viver como Ressuscitados).
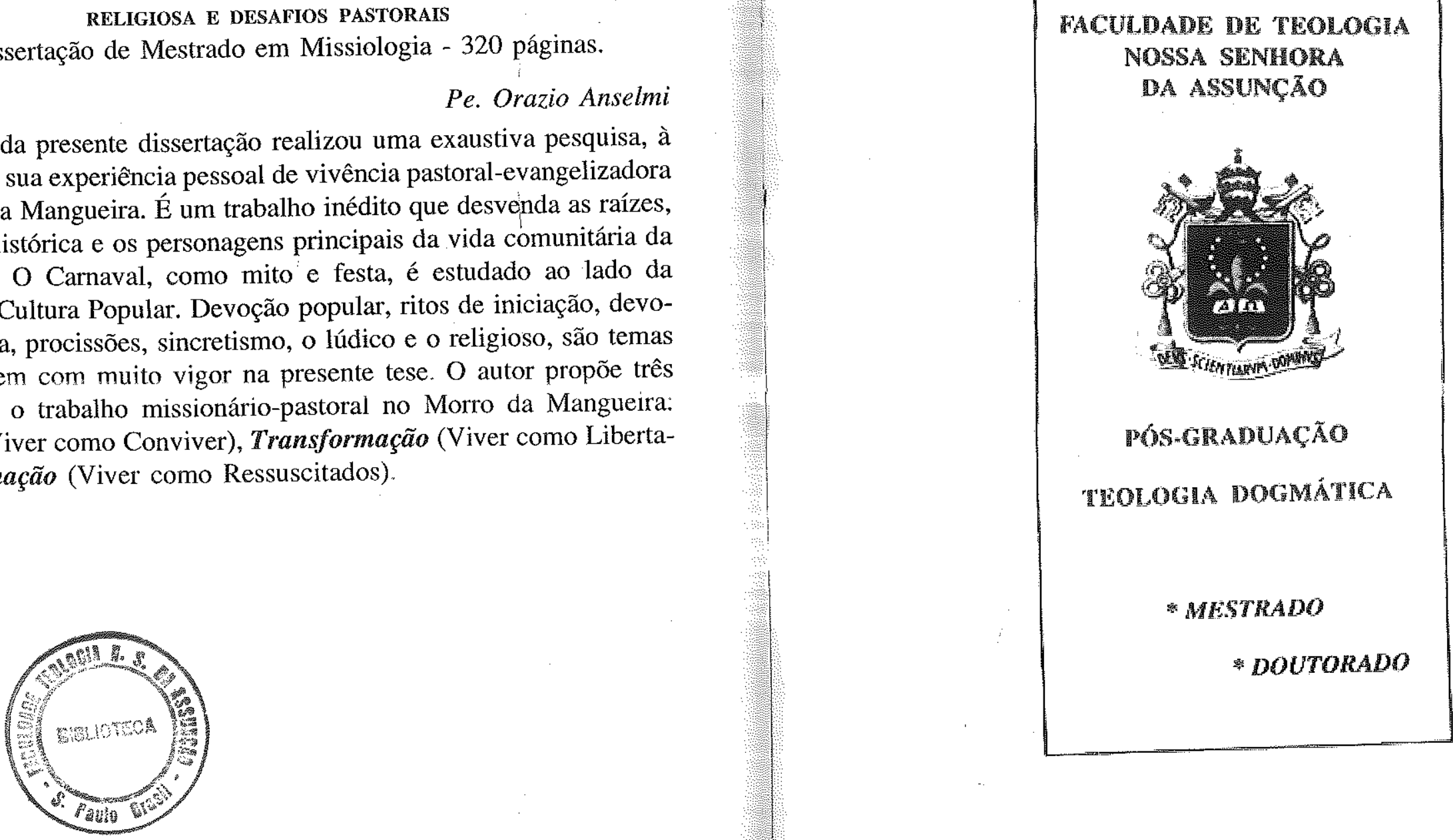